\title{
APONTAMENTOS SOBRE O DIREITO À INTIMIDADE NO ÂMBITO DO CONTRATO DE TRABALHO
}

\author{
NOTES ON THE RIGHT TO PRIVACY UNDER LABOR CONTRACTS
}

Estêvão Mallet

\begin{abstract}
Resumo:
O presente artigo trata do direito à intimidade no contrato de trabalho, tema ainda pouco explorado pela legislação brasileira. Mostra sua conexão direta com os direitos fundamentais previstos na Constituição e, assim, a sua amplitude e limitações no âmbito da relação de emprego, inclusive por conta do poder diretivo do empregador. Um estudo comparativo entre as legislações brasileira e de diversos outros países, entre eles França, Itália, Portugal, Espanha, Estados Unidos, Inglaterra, Suíça, Canadá e Argentina, busca o equilíbrio entre a necessidade de fiscalização e a preservação dos direitos do empregado e do empregador. Ressaltando a importância da bilateralidade do tema, o texto é concluído com os meios de proteção do direito em análise.

Palavras-chaves: Direito à intimidade. Direitos de personalidade. Poder diretivo do empregador. Bilateralidade do Direito. Tutela da intimidade.
\end{abstract}

\begin{abstract}
:
This article deals with the right of privacy in labor contracts, an unexplored subject in the Brazilian Law as should be. It shows its direct connection with fundamental rights in the Constitution and, thus, its range and limitations to the labor relation, including the Employer's Managerial Power. A comparative study among the Brazilian Legislation and other countries, such as France, Italy, Portugal, Spain, U.S.A., England, Switzerland, Canada and Argentina, seeks the balance between the supervision and preservation of the Employer and Employees' rights. Emphasizing the importance of the bilateralism of this subject, the text finishes with the methods of protection of rights under analysis.
\end{abstract}

Keywords: Right to Privacy. Personality Rights. Employer's Managerial Power. Bilateralism of the Rights. Protection of Privacy.

\section{Introdução}

Do direito à intimidade - correspondente ao "right to be let alone" do direito norte-americano, ${ }^{1}$ - não se ocupou expressamente a Consolidação das Leis do Trabalho, ao menos não de início, quando editada. Prevaleceu visão bastante reducionista da relação de emprego, tratada como se nela as obrigações das partes se restringissem à prestação do trabalho pelo empregado, de um lado, e ao pagamento da remuneração pelo empregador, de outro lado. Era o cenário antes dominante em matéria trabalhista, tanto que igualmente

\footnotetext{
Professor Associado de Direito do Trabalho da Faculdade de Direito da Universidade de São Paulo, Conselheiro da Ordem dos Advogados do Brasil, Secção de São Paulo e advogado.

1 Cf. BLACK, Henry Campbell. Black's Law Dictionary. St. Paul: West Publishing, 1968. p. 1.358.
} 
presente em outros sistemas jurídicos. Em França, por exemplo, a doutrina assinala que, de início, sobre os direitos de personalidade, no campo trabalhista, havia quase completa abstenção. $^{2}$

É, todavia, inaceitável a restrição. Quanto mais não seja, há que reconhecer o caráter fundamental do direito à intimidade, que radica, segundo assinalado pela doutrina norte-americana, na própria Constituição, ainda quando não previsto de modo explícito. ${ }^{3}$

Passo inicial importante no sentido de abandonar a concepção reducionista foi dado pela Lei italiana n. 300, de 20 de maio de 1970, conhecida como Statuto dei diritti dei lavoratori, a qual principia com o Título dedicado à "libertà e dignità del lavoratore". Merece referência, outrossim, o art. 328, n. 1, do Código suíço das obrigações, em que se lê:

L'employeur protège et respecte, dans les rapports de travail, la personnalité du travailleur; il manifeste les égards voulus pour sa santé et veille au maintien de la moralité. En particulier, il veille à ce que les travailleurs ne soient pas harcelés sexuellement et qu'ils ne soient pas, le cas échéant, désavantagés en raison de tels actes.

Outro passo muito importante corresponde ao Código do Trabalho de Portugal, aprovado em agosto de 2003 e em vigor desde $1^{\circ}$ de dezembro do mesmo ano, em cujos arts. $15^{\circ}$ a $21^{\circ}$ continha-se toda uma subseção dedicada aos direitos de personalidade no âmbito da relação de emprego, com referência específica ao direito à preservação da "intimidade da vida privada". ${ }^{4}$ A reforma do texto do Código, levada a cabo pela Lei n. 7/2009, de 12 de fevereiro de 2009, não modificou o quadro. Pelo contrário, ampliou a tutela legal, com a previsão, antes inexistente, de proteção de dados biométricos, consoante a regra do novo art. $18^{\circ} .^{5}$

\section{Direito brasileiro}

No Brasil o tema da intimidade das partes envolvidas no contrato de trabalho sempre teve menor importância. Durante várias décadas foi completamente negligenciado,

Cf. GAUDU, François; VATINET, Raymond. Les contrats du travail. Paris: LGDJ, 2001. n. 209, p. 179.

3 KIONKA, Edward J. Torts. St. Paul: West Publishing, 1977. p. 169. Mais amplamente, BARKER, John. Constitutional privacy rights in the private workplace, under the Federal and California Constitutions. Hastings Constitutional Law Quarterly, v. 19, p. 1.107 e ss., e, ainda, CLARK, R. H. Constitutional sources of the penumbral right to privacy. Villanova Law Review, v. 19, p. 833 e segs. Na jurisprudência norte-americana, identificando, na Constituição, os fundamentos da proteção à intimidade, cf. United States Court of Appeals for the Seventh Circuit, Kristin A. Greenwalt v. Indiana Department of Corrections, n. 04-1997, decisão de 14.02.05.

4 Art. $16^{\circ}$, n. 1 .

5 Tem a seguinte redação o novo dispositivo: “Art. $18 .^{\circ}$ Dados biométricos. 1. O empregador só pode tratar dados biométricos do trabalhador após notificação à Comissão Nacional de Protecção de Dados. 2. O tratamento de dados biométricos só é permitido se os dados a utilizar forem necessários, adequados e proporcionais aos objectivos a atingir". 
inclusive pela doutrina. Mesmo os melhores manuais de Direito do Trabalho não atentaram para a importância do assunto. ${ }^{6}$

Ganhou a proteção da intimidade alguma expressão somente com a Lei n. 9.799, de 26 de maio de 1999, que introduziu, na Consolidação das Leis do Trabalho, o art. 373-A, proibindo, no inciso VI, “revistas íntimas nas empregadas ou funcionárias”. É evidente que esse dispositivo, impreciso, incompleto, mal situado e deficiente, nem esgota a tutela legal e nem resolve todos os problemas suscitados pelo direito à intimidade no âmbito do contrato de trabalho.

3. Direitos fundamentais e direito à intimidade

O empregado, no momento em que celebra um contrato de trabalho, não se despoja, como soa evidente, de seus direitos fundamentais, entre os quais se colocam os direitos de personalidade. Como assentado pelo o Tribunal Constitucional espanhol, "a celebração de um contrato de trabalho não implica, de modo nenhum, a privação para uma das partes, o trabalhador, dos direitos que a Constituição lhe reconhece como cidadão, pois nem as organizações empresariais estão inseridas em mundos separados e estanques do resto da sociedade, nem a liberdade de empresa, prevista no art. $38^{\circ}$ do texto constitucional, legitima que aqueles que prestam serviços naquelas, por conta e na dependência dos seus titulares, devam suportar esbulhos transitórios ou limitações injustificadas dos seus direitos fundamentais". 7

Tem o empregado, portanto, o direito à preservação de sua intimidade, a despeito das limitações a que se sujeita, em decorrência do contrato de trabalho, como realçado em decisão com a seguinte ementa: "A inserção do empregado no ambiente de trabalho não lhe retira os direitos da personalidade, dos quais o direito à intimidade constitui uma espécie". ${ }^{8}$ Aliás, a Corte Européia de Direitos Humanos, certa feita deparou-se com a necessidade de interpretar o art. $8^{\circ}$, da Convenção Européia de Direitos do Homem, assim redigido, para decidir sobre sua aplicação no campo trabalhista:

1. Toute personne a droit au respect de sa vie privée et familiale, de son domicile et de sa correspondance. 2. Il ne peut y avoir ingérence d'une autorité publique dans l'exercice de ce droit que pour autant que cette ingérence est prévue par la loi et qu'elle constitue une mesure qui, dans une société

\footnotetext{
Cf., por exemplo, a obra de (MAGANO, Octavio Bueno. Manual de direito do trabalho. São Paulo: LTr, 4 v.), sempre tão profunda, na qual não se encontra, porém, referência ao direito à intimidade no campo trabalhista. Apud GUERRA, Amadeu. A privacidade no local de trabalho. Coimbra: Almedina, 2004. p. 37.

8 TRT $-3^{\mathrm{a}}$ Reg., $2^{\mathrm{a}}$ T., RO n. 16.022/2001, Rel. Juíza Alice Monteiro de Barros, julg. em 29.01.2002 in DJMG

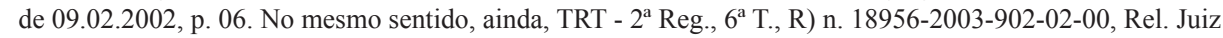
Valdir Florindo, Ac. n. 20030363599, julg. em 22.07.03 in DOE SP, PJ, TRT 2a de 01.08.03.
} 
démocratique, est nécessaire à la sécurité nationale, à la sûreté publique, au bien-être économique du pays, à la défense de l'ordre et à la prévention des infractions pénales, à la protection de la santé ou de la morale, ou à la protection des droits et libertés d'autrui". Assinalou a Corte, a propósito, que "aucune raison de principe ne permet d'exclure les activités professionnelles ou commerciales de la notion de vie privée". 9 Já antes, no caso Halford v. Reino Unido, a mesma Corte havia decidido, em hipótese envolvendo interceptação telefônica de conversa de empregado realizada no local de trabalho: "44. Pour la Cour, il ressort clairement de sa jurisprudence que les appels téléphoniques émanant de locaux professionnels, tout comme ceux provenant du domicile, peuvent se trouver compris dans les notions de "vie privée" et de "correspondance" visées à l'article 8 par. 1 (art. 8-1)". ${ }^{10}$

Mas os direitos de personalidade, inclusive o direito à intimidade, não são ilimitados. ${ }^{11}$ Ainda que se afirme a natureza fundamental de certos direitos de personalidade, compreendido o direito à intimidade, nem assim cabe considerá-los ilimitados. " $\mathrm{Al}$ concetto di diritto - adverte Ferrara - non è incompatibile quello di limite, anzi vi è inerente". ${ }^{13}$ É lícito dizer, pois, que "the right to privacy is, like any other right, a relative one that must be balanced in relation to other rights", ${ }^{14}$ considerados tanto limites expressos como, ainda, limites implícitos. ${ }^{15}$ É preciso, em conseqüência, examinar as limitações a que se sujeita o direito à intimidade no âmbito da relação de emprego, especialmente a partir do poder de fiscalização atribuído por lei ao empregador.

\section{Direito à intimidade e poder de fiscalização}

Em matéria de relação de emprego, o principal limite imposto ao direito à intimidade do empregado resulta exatamente do poder diretivo do empregador. De fato, empregador é, nos termos do caput, do art. $2^{\circ}$, da CLT, aquele que, além de outros atributos, acha-se investido da prerrogativa de dirigir a prestação pessoal de serviço. Dessa prerrogativa deflui o direito de fiscalizar o cumprimento das obrigações contratuais do empregado. Nas palavras de Octavio Bueno Magano, encontra-se o empregador

Caso Rotaru v. Romênia, processo n. 28.341/95, decisão de 4 de maio de 2000, § 43.

Processo n. 20.605/92, em decisão de 25 de junho de 1997.

ASCENSÃO, José de Oliveira. Direito civil: teoria geral. Coimbra: Coimbra Editora, 2000. v. I, n. 48, p. 92.

FAVOREU, Louis et al. Droit des libertés fondamentales. Paris: Dalloz, 2000. p. 185, n. 198.

FERRARA, Francesco. Trattato di diritto civile italiano. Roma: Athenaeum, 1921. p. 393.

4 BLANPAIN, Roger. Employee privacy issues: belgian report. Comparative Labor Law Journal, v. 17, p. 40.

15 QUEIROZ, Cristina M. M. Direitos fundamentais: teoria geral. Coimbra: Coimbra Editora, 2002. p. 200. 
legitimamente habilitado a acompanhar a atividade do empregado, "para verificar a sua conformidade com as ordens dadas". ${ }^{16}$

Em conseqüência, da consagração da inviolabilidade da vida privada da pessoa natural, no art. 21, do Código Civil, não se pode tirar a proibição total e absoluta de fiscalização, pelo empregador, da atividade do empregado. Isso levaria a evidente paradoxo: a existência de relação de emprego sem elemento essencial à configuração do poder diretivo. Como, porém, compatibilizar o direito do empregador de fiscalizar a prestação pessoal de serviço, inerente ao contrato de trabalho, com a preservação da intimidade do empregado, direito de personalidade de que não se priva aquele que aceita prestar serviços de forma subordinada? Em outros termos, quais os limites para a legítima fiscalização da atividade do empregado?

O problema suscitado longe está de ser de fácil resolução, dada a relevância e a plasticidade dos valores em conflito. Sua importância, ademais, é manifesta, especialmente se considerados os novos meios de fiscalização propiciados por aparatos eletrônicos - como câmeras de circuito fechado de televisão colocadas no local de trabalho ou programas instalados no computador da empresa, para rastrear páginas consultadas na rede mundial (Internet) ou mensagens eletrônicas enviadas e recebidas - que expõem muito mais intensamente a intimidade do empregado. Em termos simples e diretos, "the technical possibilities to learn everything there is to know about an employee have increased enormously". ${ }^{17}$

\section{Fiscalização por meio eletrônico}

Em vários sistemas jurídicos encontra-se proibição expressa de fiscalização do trabalho por meio eletrônico ou com o auxílio de câmeras de circuito fechado de televisão. É o que se vê, por exemplo, no direito italiano, por força do art. 4, n. 1, do Statuto dei diritti dei lavoratori, a preceituar: "È vietato l'uso di impianti audiovisivi e di altre apparecchiature per finalità di controlo a distanza dell'attività dei lavoratori”. Não é diferente o direito português, em virtude do art. 20, n. 1, do Código do Trabalho, verbis: "O empregador não pode utilizar meios de vigilância à distância no local de trabalho, mediante o emprego de equipamento tecnológico, com a finalidade de controlar o desempenho profissional do trabalhador".

No sistema jurídico brasileiro não se encontra proibição do gênero. Devese considerar lícita, via de conseqüência, a prática, ${ }^{18}$ já recomendada pela jurisprudência

16 MAGANO, Octavio Bueno. Do poder diretivo na empresa. São Paulo: Saraiva, 1982. n. 61, p. 118.

17 BLANPAIN, Roger. Employee privacy issues: belgian report. cit., p. 39.

18 JAVILLIER, Jean-Claude. Droit du Travail. Paris: Dalloz, 1999. n. 334, p. 437. 
nacional ${ }^{19}$ e admitida, aliás, no direito espanhol, em que o art. 20, n. 3, do Estatuto de los Trabajadores preceitua: "El empresario podrá adoptar las medidas que estime más oportunas de vigilancia y control para verificar el cumplimiento por el trabajador de sus obligaciones y deberes laborales, guardando en su adopción y aplicación la consideración debida a su dignidad humana y teniendo en cuenta la capacidad real de los trabajadores disminuidos, en su caso".

Admitir a licitude de meios eletrônicos de fiscalização não significa, porém, enunciar a regularidade, em termos gerais, de tudo e qualquer expediente que venha o empregador a adotar. Muito ao contrário, para que seja legítima a fiscalização, é de rigor observar certos limites. Quando são eles desrespeitados, há ilicitude na fiscalização.

Em primeiro lugar, é preciso que a fiscalização objetivamente se justifique. Deve haver um motivo relevante para que o meio eletrônico seja empregado como, entre outros, a segurança dos empregados ou de terceiros, a proteção do patrimônio da empresa etc. Se é expediente gratuito, praticado por emulação pelo empregador, sem que se mostre necessário, revela-se, só por isso, abusivo.

Ademais, a fiscalização eletrônica, além de necessária há de ser feita sempre com transparência. É preciso informar previamente o empregado da existência do aparato de controle, consoante teve o cuidado de registrar a jurisprudência nacional. ${ }^{20}$ É também o que no direito francês se dá, a partir do texto do art. L. 432-2-1, n. 3, do Code du Travail: “Le comité d'entreprise est informé et consulté, préalablement à la décision de mise en oeuvre dans l'entreprise, sur les moyens ou les techniques permettant un contrôle de l'activité des salariés". Na legislação da Nova Gales do Sul, na Austrália, conquanto o Workplace Video Surveillance Act, de 1998, proíba, como regra geral, em sua seção 7 , n. 1, a fiscalização do trabalho do empregado por meio de câmeras de vídeo, admite a prática em circunstâncias limitadas, envolvendo "the purpose of ensuring the security of the workplace or persons in it"(sec. 7, n. 3, "a"), e, ainda assim, desde que "the employer has notified employees at the workplace (or a body representing a substantial number of the employees) in writing of the intended video surveillance for the purpose referred to in that subsection before it is carried out”. (sec. 7, n. 4). Em síntese, parece inegável que qualquer forma de vigilância clandestina, oculta ou dissimulada, é ilícita e incompatível,

19 TST - 2 ${ }^{\text {a }}$ T., RR n. 533.779/1999, Rel. Juiz Convocado Samuel Corrêa Leite, julg. em 26.11. 2003 in DJU de 06.02.2004.

20 Na jurisprudência nacional: "Dano moral. Violação da intimidade do funcionário. A instalação de câmera no local de trabalho, com prévia ciência dos empregados, cientes inclusive onde estão, por medida de segurança patrimonial de todos, não ofende o direito à inviolabilidade da intimidade assegurado no inciso $\mathrm{X}$ do art. $5^{\circ}$, da Constituição da República”. (TRT - 3ª Reg., 2 ${ }^{\mathrm{a}}$ T., RO n. 4.165/03, Rel. Juiz José Maria Caldeira, julg. em 29.04.03 in DJMG de 07.05.03). 
in re ipsa, com a dignidade da pessoa humana, ainda quando possa a fiscalização, em tese, ser considerada admissível.

Tampouco se admite, ainda que haja prévio aviso ou comunicação, vigilância, por qualquer meio ou forma, em local por natureza reservado, como sanitários, vestiários, locais de repouso ou outros assemelhados. A ilicitude, no caso, é manifesta e já foi mesmo proclamada judicialmente, em acórdão com a seguinte ementa: "Dano moral. Prova de ato ilícito. Provado que o empregador, a pretexto de vigiar o seu patrimônio, instala câmara monitorada no vestiário, resta configurada a agressão à intimidade da empregada que freqüenta aquele recinto, daí decorrendo a lesão de ordem moral passível de reparação patrimonial", ${ }^{21}$

A utilização de meio de comunicação que de antemão se sabe não ser reservado e estar sujeito a fiscalização impede que se invoque a proteção conferida à intimidade. Há consentimento à quebra da intimidade, que atua como pré-excludente de ilicitude, ${ }^{22}$ independentemente de prévia autorização judicial. ${ }^{23}$ Quem envia mensagem em cartão postal, por exemplo, não pode queixar-se de haver sido ela lida. É algo que seria de ocorrência previsível. Assim, não se afigura ilegal a gravação de conversa telefônica que o empregado entabula no aparelho cedido pela empresa, para uso durante o serviço e em atividade ligada ao objeto do contrato de trabalho, sempre que previamente divulgado o procedimento de fiscalização. A prática tem especial importância - e não tem como ser questionada - quando há necessidade de comprovação da conversa, tal como se dá em casos de operações bancárias ou de compras realizadas por meio de telefone.

A jurisprudência nacional tem ido além, para admitir, em termos gerais, o rastreamento de páginas consultadas na rede mundial (Internet), bem como o exame de mensagens eletrônicas, enviadas por meio do endereço fornecido ao empregado, para uso apenas em serviço. Adota-se a idéia de não existir, no caso, expectativa de privacidade,

${ }_{21}$ TRT $-3^{\mathrm{a}}$ Reg., $1^{\mathrm{a}}$ T., RO n. 15.740/01, Rel. Juiz José Marlon de Freitas, julg. em 17.12.01 in DJMG de 08.02.02.

22 MIRANDA, Francisco Cavalcanti Pontes de. Tratado de direito privado. Rio de Janeiro: Borsoi, 1955. tomo VII, $\S 755$, n. 2. p. 125.

23 Em sentido contrário, porém: "Pedido de produção de prova fonografodocumentoscópica denegado - Falta de autorização judicial para instalação de escuta telefônica - Inexistência de cerceio de defesa. Estando as decisões das instâncias ordinárias alicerçadas no inciso XII do art. $5^{\circ}$ da Constituição Federal, que exige a autorização judicial para a quebra do sigilo das comunicações telefônicas, não há que se falar em cerceio de defesa, quando negado o pedido de prova pericial (exame fonografodocumentoscópico) visando a confirmar a procedência da voz gravada, se a escuta telefônica procedida pela Reclamada fez-se sem a referida autorização. Acresça-se a isso o magistério do STF, que, intérprete máximo da Constituição, aponta para a impossibilidade de admissão da escuta telefônica, sem autorização judicial prévia, como meio de prova lícito. De fato, a ilicitude da forma como produzida a prova, sem atenção à designação da lei, culminaria na contaminação de todos os atos processuais nela lastreados, entre os quais a perícia fonografodocumentoscópica, figurando, aí, a indesejada conseqüência preconizada pela "Teoria dos Frutos da Árvore Envenenada" ("Fruits of the Poisonous Tree")". (TST - 4 T., RR n. 373.356/97, Rel. Min. Ives Gandra Martins Filho, julg. em 12.12.01 in DJU de 01.03.02). 
como assinalado pelo Tribunal Superior do Trabalho, ao validar prova obtida com o exame de mensagem eletrônica enviada pelo empregado, a partir do endereço para uso apenas em serviço. Aduziu-se, na altura:

o e-mail corporativo não desfruta da mesma proteção outorgada à correspondência de natureza pessoal. É simples instrumento de trabalho, que o Empregador confia ao Empregado para auxiliá-lo no desempenho de suas atividades laborais. Penso, por conseguinte, que se o e-mail corporativo pertence à Reclamada, se é instrumento de trabalho, se não existe expectativa de privacidade com relação às mensagens enviadas, pode o Empregador monitorar a atividade do Empregado, no horário de trabalho. ${ }^{24}$

Na jurisprudência estrangeira, no entanto, a conclusão por vezes é outra. No célebre precedente Nikon, a Corte de Cassação francesa considerou ilegítima a devassa, feita pelo empregador, de mensagem enviada por empregado a partir do endereço eletrônico da empresa, mesmo existindo proibição de uso, para fins particulares, do meio de comunicação. Do pronunciamento extraem-se as seguintes considerações:

...le salarié a droit, même au temps et au lieu de travail, au respect de l'intimité de sa vie privée...celle-ci implique en particulier le secret des correspondances...l'employeur ne peut dès lors sans violation de cette liberté fondamentale prendre connaissance des messages personnels émis par le salarié et reçus par lui grâce à un outil informatique mis à sa disposition pour son travail et ceci même au cas où l'employeur aurait interdit une utilisation non professionnelle de l'ordinateur. ${ }^{25}$

Mas o direito à intimidade reconhecido pela jurisprudência francesa não se reveste, porém, de caráter absoluto. Nem poderia revestir-se. Por isso, a mesma Cour de Cassation teve oportunidade de explicitar a aplicabilidade, em matéria trabalhista, da regra do art. 145, do Code de procédure civile, assim redigido: "S'il existe un motif légitime de conserver ou d'établir avant tout procès la preuve de faits dont pourrait dépendre la solution d'un litige, les mesures d'instruction légalement admissibles peuvent être ordonnées à la

24 TST - $1^{a}$ T., Proc. RR-613/2000-013-10-00.7, Rel. Min. João Oreste Dalazen, julg. em 18.05.2005 in DJU de 10.06.2005. A mesma solução voltou a prevalecer em outro julgamento, também do Tribunal Superior do Trabalho, em que se registrou: "se o empregado eventualmente se utiliza da caixa de "e-mail" corporativo para assuntos particulares, deve fazê-lo consciente de que o seu acesso pelo empregador não representa violação de suas correspondências pessoais, tampouco violação de sua privacidade ou intimidade, porque se trata de equipamento e tecnologia fornecidos pelo empregador para utilização no trabalho e para alcance das finalidades da empresa" (TST - 7 T., AIRR-1.542/2005-055-02-40.4, Rel. Min. Ives Gandra Martins Filho, julg. em 04.06. 2008 in DJU de 06/06/2008).

25 Cour de Cassation, Chambre sociale, Société Nikon France SA c. Frédéric Onof, Proc. 99-42.942, Arrêt n. 4164, de 02.10. 2001. Na linha da jurisprudência francesa, em doutrina, GUERRA, Amadeu. A privacidade no local de trabalho. cit., p. 386. 
demande de tout intéressé, sur requête ou en référé”. Assinalaou a decisão tomada após o acórdão Nikon, “...le respect de la vie personnelle du salarié ne constitue pas en luimême un obstacle à l'application des dispositions de l'article 145 du nouveau code de procédure civile dès lors que le juge constate que les mesures qu'il ordonne procèdent d'un motif légitime et sont nécessaires à la protection des droits de la partie qui les a sollicitées". ${ }^{26}$ Logo, para examinar mensagens enviadas ou recebidas pelo empregado, quando presente motivo legítimo para tanto, por conta de suspeita de uso irregular do meio de comunicação, prática de ilícito, concorrência desleal ou outra circunstância ponderosa, deve o empregador pedir autorização judicial, a fim de que a investigação se faça por meio de oficial de justiça, nomeado pelo tribunal.

6. Revista pessoal e de pertences

A CLT não contém regra abrangente sobre os limites à fiscalização da atividade do empregado por meio de revista pessoal. Somente veda, como já mencionado, o que chamou de revista íntima (art. 373-A, inciso IV). Conquanto tenha o legislador proibido tal prática apenas em relação à mulher - tanto que inseriu o dispositivo no Capítulo dedicado à proteção do trabalho feminino -, é evidente que se há de interpretar a norma ampliativamente, a fim de adequá-la ao princípio da isonomia (art. $5^{\circ}$, caput, e inciso I, da Constituição), de modo que o mesmo óbice favoreça todos os trabalhadores, inclusive menores e homens.

Outras formas de revista ou de inspeção, que não tenham caráter íntimo, encontram amparo no poder diretivo do empregador ${ }^{27}$ e não violam o dever de boa-fé contratual. Não estão, portanto, peremptoriamente afastadas. A jurisprudência teve oportunidade de assinalar:

Indenização por dano moral. Revista. $O$ fato de a empregadora possuir como atividade-fim o transporte e a guarda de dinheiro, bem suscetível de subtração e ocultação, justifica uma fiscalização mais rigorosa, inclusive a revista, como meio de proteger o patrimônio do empregador, mesmo porque não há na legislação brasileira nenhum dispositivo legal proibindo expressamente a inspeção e perquirição pessoal, como ocorre na legislação italiana. Aliás, o art. 373A da CLT, inserido no capítulo do trabalho da mulher, até permite a revista, desde que não seja vexatória... ${ }^{28}$

\footnotetext{
${ }^{26}$ Cour de cassation, Chambre Sociale, Société Datacep SA c. Lionel X, Proc. 05-17.818, Arrêt n. 1146 , de 23.05.2007.

27 VIVOT, Julio J. Martínez. Elementos del derecho del trabajo y de la seguridad social. Buenos Aires: Astrea, 1996. p. 146.

28 TRT $-3^{\text {a Reg., }} 2^{\text {a }}$ T., Rel. Juíza Alice Monteiro de Barros julg. em 30.10.2001, RO n. 13.305/2001, in DJMG
} 
Tanto é correta a idéia de que as revistas não estão peremptoriamente afastadas da relação de emprego que a Ley de Contrato de Trabajo argentina, embora expressamente imponha aos sujeitos ligados por vínculo de emprego a obrigação de "obrar de buena fe, ajustando su conducta a lo que es propio de un buen empleador y de un buen trabajador, tanto al celebrar, ejecutar o extinguir el contrato o la relación de trabajo", ${ }^{29}$ não exclui, antes permite, a utilização de "sistemas de controles personales del trabajador destinados a la protección de los bienes del empleador". ${ }^{30}$ A mesma conclusão estende-se ao exame de bolsas, sacolas ou armários. Seria mesmo contraditório admitir-se a revista de pessoas e não a de seus pertences.

Em qualquer caso, porém, há diversos limites a observar. Em primeiro lugar, a providência há de ser, tal qual a fiscalização eletrônica, tratada anteriormente, necessária ou, como oportunamente ressaltado pela doutrina italiana, "seriamente consigliabili per la tutela del patrimonio aziendale". ${ }^{31}$ Não basta sua simples conveniência ou sua maior comodidade para o empregador. ${ }^{32}$

Exige-se, outrossim, equilíbrio entre a medida aplicada e o fim a atingir-se. A providência adotada deve ser la moins intrusive parmi toutes celles possibles, como nota a doutrina suíça. ${ }^{33}$ Daí que, se o mesmo resultado puder ser obtido até sem a revista - por meio de outros sistemas de segurança -, fica ela vedada, pura e simplesmente. Mera

de 14.11.2001, p. 21. Na mesma linha, ainda: "Indenização por danos morais. Revista. Na qualidade de dono e gestor do empreendimento econômico, o empregador não só pode, como deve proteger seu patrimônio, especialmente quando exerce atividade-fim ligada à comercialização de produtos de valor considerável, de fácil subtração e/ou ocultação. Desde que o exercício do poder diretivo seja regular, impessoal, genérico e não atente contra o pudor do homem médio, tem a faculdade, inclusive, de realizar revistas que não ofendam a intimidade do empregado e não o exponham a situações vexatórias e humilhantes" (TRT - $3^{\mathrm{a}}$ Reg., $2^{\mathrm{a}} \mathrm{T}$., RO n. 14.596/2001, Rel. Juiz Ricardo Marcelo Silva, julg. em 04.12.2001 in DJMG de 12.12.2001, p. 21) e "Dano moral. Indenização. O fato de a empresa trabalhar com produtos farmacêuticos, inclusive psicotrópicos, realmente justifica fiscalização rigorosa, inclusive a revista, já que o empregador está obrigado a zelar para que medicamentos não sejam objeto de tráfico ilícito, evitando a sua comercialização indiscriminada". (TRT - $3^{\text {a }}$ Reg., $5^{\text {a }}$ T., RO n. 8932/97, Rel. Juiz Fernando Antônio Ferreira in DJMG de 30.05.1.998, p. 15). No mesmo sentido, em doutrina, BARROS, Alice Monteiro de. Proteção à intimidade do empregado. São Paulo: LTr, 1997. p. 74; MAGANO, Octavio Bueno. Direito individual do trabalho. São Paulo: LTr, 1992. p. 212, e SUSSEKIND, Arnaldo; CARVALHO, Luiz Inácio. Revista do empregado: limites. In: Direito do trabalho e previdência social: pareceres. São Paulo: Ltr, 1995. v. 10, p. 221. Em sentido contrário, negando genericamente a possibilidade de revistas, SIMÓN, Sandra Lia. A proteção constitucional da intimidade e da vida privada do empregado. São Paulo: LTr, 2000. p. 149, e BARACAT, Eduardo Milléo. A boa-fé no Direito Individual do Trabalho. São Paulo: LTr, 2003. p. 243. Na jurisprudência, também rejeitando a possibilidade de revistas: “... não há circunstância que autorize o empregador a proceder à revista de seus empregados..."(TST $-2^{\mathrm{a}} \mathrm{T}$., RR n. 533.779/1999, Rel. Juiz Convocado Samuel Corrêa Leite, julg. em 26.11. 2003 in DJU de 06.02.2004).

29 Art. 63.

30 Art. 70 .

31 ASSANTI, Cecília; PERA, Giuseppe. Commento allo statuto dei diritti dei lavoratori. Padova: CEDAM, 1972. p. 68.

32 GARCÍA-NENET, José Ignácio. El Estatuto de los Trabajadores: comentarios a la Ley 8/1980. Madrid: Editoriales de Derecho Reunidas, 1981. p. 146.

33 WYLER, Rémy. Droit du travail. Berne: Staempfli, 2002. p. 224. 
decorrência do princípio geral da proporcionalidade, seguidamente invocado no âmbito do controle de constitucionalidade das leis, mas já utilizado em matéria de direito de personalidade, para preservação da dignidade da pessoa. ${ }^{34}$

Deve o empregado, de outro lado, ser previamente avisado da possibilidade da revista, tal como se impõe, segundo sublinhado acima, para o uso de equipamentos eletrônicos de fiscalização. Não se faz necessária, todavia, prévia autorização judicial, ao contrário do que já se pretendeu. ${ }^{35}$

De outra parte, é preciso, ainda, que a revista não ofenda a dignidade do trabalhador, como disposto no art. 18, do Estatuto de los Trabajadores da Espanha, nos seguintes termos:

Sólo podrán realizarse registros sobre la persona del trabajador, en sus taquillas y efectos particulares, cuando sean necesarios para la protección del patrimonio empresarial y del de los demás trabajadores de la empresa, dentro del centro de trabajo y en horas de trabajo. En su realización se respetará al máximo la dignidad e intimidad del trabajador y se contará con la asistencia de un representante legal de los trabajadores o, en su ausencia del centro de trabajo, de otro trabajador de la empresa, siempre que ello fuera posible.

A revista há de fazer-se, portanto, em local reservado, por pessoa do mesmo sexo se implicar alguma forma de contato físico, sem exposição do empregado em local aberto. Seus pertences, durante o procedimento de revista, não podem ser danificados ou lançados aos olhares de terceiros, sem relação com a fiscalização.

Por fim, nenhum procedimento de revista poderá ter caráter discriminatório ou persecutório. Não é possível, por exemplo, sujeitar a revista apenas os empregados de determinado sexo ou aqueles provenientes de determinada região do país ou, ainda, os que recebem menos do que certo valor de salário. A exigência de adoção de critérios legítimos de seleção dos empregados a fiscalizar não significa, todavia, obrigação de extensão da medida a todos, sem nenhuma distinção, como impropriamente determina a legislação argentina, em cuja Ley de Contrato de Trabajo estatui-se:

\footnotetext{
34 Trata-se de acórdão do Supremo Tribunal Federal, com a seguinte ementa: "DNA: submissão compulsória ao fornecimento de sangue para a pesquisa do DNA.... deferimento... do HC na espécie, em que se cuida de situação atípica na qual se pretende - de resto, apenas para obter prova de reforço - submeter ao exame o pai presumido, em processo que tem por objeto a pretensão de terceiro de ver-se declarado o pai biológico da criança nascida na constância do casamento do paciente: hipótese na qual, à luz do princípio da proporcionalidade ou da razoabilidade, se impõe evitar a afronta à dignidade pessoal que, nas circunstâncias, a sua participação na perícia substantivaria."(STF $-1^{\text {a }}$ T., HC 76060/SC, Rel. Min. Sepúlveda Pertence, julg. em 31.03.1998 in DJU de 15.05.1998, p. 44).

35 MEIRELES, Edilton. O novo código civil e o direito do trabalho. São Paulo: LTr, 2002. p. 19.
} 
Los sistemas de controles personales del trabajador destinados a la protección de los bienes del empleador deberán siempre salvaguardar la dignidad del trabajador y deberán practicarse con discreción y se harán por medios de selección automática destinados a la totalidad del personal. ${ }^{36}$

A revista pode não ser necessária indistintamente, em todos os setores da empresa. Pode fazer sentido fiscalizar apenas certos empregados e não outros. Sujeitar todos ao procedimento, inclusive aqueles que não precisam ser fiscalizados, apenas para assegurar igualdade de tratamento, não faz nenhum sentido e nem favorece a tutela da intimidade. Impostergável é, na verdade, a observância de parâmetros imparciais e objetivos de seleção dos que serão revistados, ${ }^{37}$ conforme explicitado, aliás, no art. 43 , do Código de Trabajo da República Dominica, assim redigido:

\begin{abstract}
Los sistemas de controles personales del trabajador destinados a la protección de los bienes del empleador deben siempre salvaguardar la dignidad del trabajador y deben practicarse con discreción y según criterios de selección objetivos, los que deben tener en cuenta la naturaleza de la empresa, el establecimiento o el taller en donde deben aplicarse. Los sistemas, en todo los casos, deben ser puestos en conocimiento del Departamento de Trabajo o de la autoridad local que ejerza sus funciones, que están facultados para verificar si los mismos no afectan en forma manifiesta y discriminada la dignidad del trabajador.
\end{abstract}

Se não se faz de tal modo, há ilicitude, não pelo ato em si da revista, mas pela forma ilegítima e abusiva como ela é realizada (Código Civil, art. 187). Vale, no caso, a observação de Josserand: "il ne suffit pas d'exercer nos droits conformément à la bonne foi, il faut encore les réaliser correctement, prudemment". 38

\title{
7. Direito à intimidade e direito de informação
}

Outro aspecto delicado da intimidade do empregado relaciona-se com as informações que pode o empregador exigir ou apenas solicitar no momento da seleção de candidatos, da contratação ou durante a vigência da relação de trabalho.

Há certas informações cuja prestação é obrigatória, de modo que o empregador as pode legitimamente exigir. É o caso do endereço do empregado, tendo em conta a regulamentação estabelecida para o benefício do vale-transporte. ${ }^{39}$ Também o

\footnotetext{
36 Art. 70.

37 CORRADO, Renato. Trattato di diritto del lavoro. Torino: UTET, 1969. v. 3, n. 125, p. 293.

38 JOSSERAND, Louis. De l'esprit des droits et de leur relativité. Paris: Dalloz, 1939. n. 286, p. 387.

39 Art. $7^{\circ}$, inciso I, do Decreto n. 95.247.
} 
número de dependentes do empregado deve ser informado, para efeito de tributação dos rendimentos decorrentes do trabalho assalariado. ${ }^{40}$

Certas outras informações, embora não obrigatórias, também podem ser pedidas, desde que, nos termos do art. $17^{\circ}$, n. 1 , alínea "a", do Código do Trabalho de Portugal, sejam "estritamente necessárias e relevantes para avaliar da aptidão (do trabalhador) no que respeita à execução do contrato de trabalho". Regra bastante próxima encontra-se no art. L. 121-6, do Código do Trabalho Francês:

Les informations demandées, sous quelque forme que ce soit, au candidat à un emploi ou à un salarié ne peuvent avoir comme finalité que d'apprécier sa capacité à occuper l'emploi proposé ou ses aptitudes professionnelles. Ces informations doivent présenter un lien direct et nécessaire avec l'emploi proposé ou avec l'évaluation des aptitudes professionnelles. Le candidat à un emploi ou le salarié est tenu d'y répondre de bonne foi.

Como se infere dos dois dispositivos legais mencionados, é preciso que haja pertinência da indagação frente aos termos do contrato de trabalho. ${ }^{41}$ A experiência anterior do empregado constitui um exemplo. Nada há de irregular em o empregador indagar o candidato ao emprego a respeito do assunto. ${ }^{42}$ Talvez se possa até mesmo falar em dever do empregado de prestar informação do gênero, independentemente de questionamento do empregador, em decorrência da boa-fé objetiva, como proposto em doutrina. ${ }^{43}$ Cumpre, porém, observar o limite imposto, no direito positivo brasileiro, pela regra do art. 442-A, da CLT.

Já algumas informações estão postas ao abrigo da ciência do empregador. Não há como validamente as solicitar, e o empregado tem a prerrogativa de não as revelar. Não pode o empregador, por exemplo, questionar o empregado sobre sua convicção política, suas preferências sexuais ou sua crença religiosa. ${ }^{44}$ É certo que, no caso dos chamados empregadores de tendência, ou seja, instituição vinculada à determinada crença ou convicção, tem-se admitido a indagação, a fim de avaliar a vinculação do empregado à crença ou convicção sufragada no ambiente de trabalho. ${ }^{45} \mathrm{Na}$ Itália, o problema colocou-se

\footnotetext{
40 Art. $4^{\circ}$, inciso III, da Lei n. 9.250, e art. 77, do Decreto n. 3.000.

41 GOFF, Jacques Le. Droit du travail et société: les relations individuelles de travail. Rennes: Presses Universitaires de Rennes, 2001. p. 195, WYLER, Rémy. Droit du travail. cit., p. 228, e ARAÚJO, Francisco Rossal de. A boa-fé no contrato de emprego. São Paulo: LTr, 1996. p. 240.

42 BARROS, Alice Monteiro de. Proteção à intimidade do empregado. cit., p. 66, e PLÁ RODRIGUEZ, Américo. Nuevos aportes sobre la protección a la intimidad del trabajador. In: Direito do trabalho: estudos em homenagem ao Prof. Luiz de Pinho Pedereira da Silva. São Paulo: LTr, 1998. p. 198.

43 CORDEIRO, António Menezes. Manual de direito do trabalho. Coimbra: Almedina, 1999. p. 559 e ARAÚJO, Francisco Rossal de. A boa-fé no contrato de emprego. cit., p. 251.

44 PALOMEQUE LÓPEZ, Manuel Carlos; ALVAREZ DE LA ROSA, Manuel. Derecho del Trabajo. Madrid: Editorial Centro de Estúdios, 2001. p. 707.

45 Invocando precedente da Corte de Cassação francesa, cf., por exemplo, LE GOFF, Jacques. Droit du travail
} 
quando se discutiu a possibilidade de vincular-se a escolha de professores, para o exercício do magistério, na Università cattolica del Sacro Cuore, à inexistência de oposição de entidade religiosa. A solução adotada pela Corte Costitizionale, favorável à prática, fundou-se nos seguintes argumentos:

La libertà della scuola intesa come attuazione del principio del pluralismo scolastico ai sensi dell'art. 33 Cost., si estende indubbiamente alle università, per cui è ammissibile la creazione di università libere, che possono essere confessionali o comunque ideologicamente caratterizzate, e ne deriva necessariamente che la libertà di insegnamento da parte di singoli docenti che sono liberi di aderire all'indirizzo della scuola come di recedere dal relativo rapporto, incontra nel particolare ordinamento di siffatte università i limiti necessari a realizzarne le finalità. Ciò vale in particolare per l'Università cattolica la cui pretesa natura di persona giuridica pubblica non ne attenuerebbe comunque l'originaria destinazione finalistica e la caratterizzazione confessionale. Negando ad una libera università ideologicamente qualificata il potere di scegliere i suoi docenti in base ad una valutazione della loro personalità e negandosi alla stessa il potere di recedere dal rapporto ove gli indirizzi religiosi o ideologici del docente siano divenuti contrastanti con quelli che caratterizzano la scuola, si mortificherebbe e rinnegherebbe la libertà di questa, inconcepibile senza la titolarità di quei poteri, e pertanto l'art. 38 del Concordato non contrasta con l'art. 33 Cost., che subordina al nulla osta della S. Sede la nomina dei professori dell'Università cattolica del Sacro Cuore. La legittima esistenza di libere università caratterizzate dalla finalità di diffondere un credo religioso è uno strumento di libertà, e la libertà religiosa dei cattolici sarebbe gravemente compromessa ove l'Università cattolica non potesse recedere dal rapporto con un docente che più non ne condivida le fondamentali e caratterizzanti finalità. 亡̀ pertanto infondata la questione di legittimità costituzionale dell'art. 38 del Concordato che subordina la nomina e la permanenza dei professori dell'Università cattolica al nulla osta della S. Sede, sollevata in relazione all'art. 19 Cost. $^{46}$

Mais tarde, a Diretiva Directiva 95/46/CE do Parlamento Europeu e do Conselho, de 24 de Outubro de 1995, referendou a solução ao dispor, no art. 8: "1. Os Estados-membros proibirão o tratamento de dados pessoais que revelem a origem racial ou étnica, as opiniões políticas, as convicções religiosas ou filosóficas, a filiação sindical, bem como o tratamento 
de dados relativos à saúde e à vida sexual. 2. O n. 1 não se aplica quando:...d) $\mathrm{O}$ tratamento for efectuado, no âmbito das suas actividades legítimas e com as garantias adequadas, por uma fundação, uma associação ou qualquer outro organismo sem fins lucrativos de carácter político, filosófico, religioso ou sindical, na condição de o tratamento dizer unicamente respeito aos membros desse organismo ou às pessoas que com ele mantenham contactos periódicos ligados às suas finalidades, e de os dados não serem comunicados a terceiros sem o consentimento das pessoas em causa...”. É, no entanto, inaceitável o regramento posto. Acima da liberdade de organização das instituições educacionais - como das organizações de tendência em geral - está a liberdade de crença, que torna ilegítima simples indagação sobre a religião do empregado ${ }^{47}$ ou mesmo a consideração de tal fator no momento de sua admissão. Afinal, como enunciado pelo art. $41^{\circ}$, n. 2, da Constituição de Portugal, "ninguém pode ser perseguido, privado de direitos ou isento de obrigações ou deveres cívicos por causa das suas convicções ou prática religiosa". Nada muda no Brasil, diante da proibição, estampada no art. 5, VIII, da Constituição, de privar-se quem quer que seja de seus direitos "por motivo de crença religiosa ou de convicção filosófica ou política".

Diante do art. $5^{\circ}, \mathrm{XLV}$, da Constituição, ficam ainda afastadas, em termos absolutos, indagações em torno de antecedentes criminais de parentes do empregado, inclusive ascendentes ou descendentes, ainda que com ele residam ou mantenham relação estreita e próxima. Como ressalta o art. $16^{\circ}$, n. 2, do Código do Trabalho de Portugal, o direito à reserva sobre a intimidade no âmbito da relação de emprego compreende a preservação de informações relacionadas com "a vida familiar, afectiva e sexual, com o estado de saúde e com as convicções políticas e religiosas".

É mais complexo o problema relacionado com a investigação de antecedentes criminais ou creditícios do próprio empregado, especialmente quando em causa esteja o exercício de atividades sensíveis, como contato com crianças, manipulação de elevadas somas de dinheiro ou manuseio de substâncias entorpecentes. A melhor construção é a que restringe a investigação a casos muito limitados - que não podem ser previamente indicados -, em respeito àquilo que se convencionou chamar, no direito português, de "direito ao esquecimento", necessário para evitar estigmatização ou discriminação de certas pessoas. ${ }^{48}$ Afinal, fosse sempre possível a investigação, sem nenhum limite temporal e sem que esteja presente uma particular e relevante justificação, o risco de marginalização de certas pessoas seria muito grande, o que não é desejável. Assim, somente diante de

\footnotetext{
47 Lembre-se, a propósito, a regra do art. 16, da Constituição espanhola: "1. Se garantiza la libertad ideológica, religiosa y de culto de los individuos y las comunidades sin más limitación, en sus manifestaciones, que la necesaria para el mantenimiento del orden público protegido por la ley. 2. Nadie podrá ser obligado a declarar sobre su ideología, religión o creencias".

48 GUERRA, Amadeu. A privacidade no local de trabalho. cit., p. 70.
} 
ponderosas circunstâncias é que se deve admitir investigação de antecedentes criminais ou creditícios do próprio empregado. ${ }^{49}$

Também se há de afastar questionamento sobre sanções disciplinares aplicadas ao empregado em outros empregos, como advertências, mesmo verbais, suspensões ou até dispensas com justa causa. Embora não exista proibição expressa da indagação, o seu caráter ilícito é decorrência da regra do art. $29, \S 3^{\circ}$, da CLT, proibitiva de que sejam feitas, na carteira de trabalho, anotações desabonadoras do empregado. Da disposição legal existente tira-se o claro propósito do legislador de impedir qualquer publicidade em torno de punições aplicadas ao empregado. Nem importa a eventual adequação e correção delas. O que se pretendeu foi impedir a divulgação da punição, para, como assinalado pelo Tribunal Superior do Trabalho, desestimular "a conduta do empregador que gera ao empregado dificuldades na tentativa de ser reaproveitado no mercado de trabalho, diante do registro na CTPS do motivo da rescisão e seu fundamento". ${ }^{50}$ Proibir a anotação da sanção, mas, ao mesmo tempo, admitir a sua divulgação verbal, seria evidente contra-senso. Assim, a finalidade da norma posta leva a que seja ela interpretada de modo ampliativo, para excluir não apenas anotação desabonadora, como, simplesmente, questionamento sobre aplicação de sanção e, mais ainda, prestação de informação desabonadora.

Se é exigível a prestação de informação, o silêncio do empregado mostra-se ilegítimo e a prestação de falsos esclarecimentos configura justa causa ${ }^{51}$ ou até mesmo, em certas situações extremas, ilícito penal. ${ }^{52}$

As questões relacionadas com informações admissíveis, mas não obrigatórias, o empregado tem a prerrogativa de não responder. Não se concebe, todavia, que preste informações falsas, afirmando, por exemplo, ter experiência muito superior à verdadeira. Há violação do dever de agir de boa-fé. Vangloriar-se de suas aptidões, ainda que não exista motivo para tanto, é, todavia, simples dolus bonus, e não configura informação falsa ou quebra da boa-fé contratual. ${ }^{53}$

49 Em termos conformes, cf. GUERRA, Amadeu. A privacidade no local de trabalho... cit., p. 87.

50 TST - 5 ${ }^{\mathrm{a}}$ T., Rel. Min. Brito Pereira, Proc. n. AIRR e RR-4.497/2001-037-12-00.5, julg. em 18.04.2007 in DJU de 18.05.2007. Veja-se, ainda, o seguinte outro aresto, em que também se explicita o fundamento da proibição contida no art. $29, \S 3^{\circ}$, da CLT: “A anotação deliberada da dispensa por justa causa na CTPS do obreiro configura a culpa do empregador no ato ilícito praticado por seu preposto, cujo dano é presumível, por se tratar de fator que impede ou, ao menos, dificulta, a recolocação no mercado de trabalho, além de causar evidente constrangimento ao trabalhador" (TRT - 15 a Reg., Proc. n. 00394-2005-111-15-00-9 ROPS, Rel. Juiz Luiz Antonio Lazarim in DJ de 30.05.2008).

51 Relativamente ao vale-transporte, cf. Decreto n. 95.247 , art. $7^{\circ}, \S 3^{\circ}$.

52 Foi o que decidiu a United States Court of Appeals for the Ninth Circuit, no julgamento n. 03-50442, de 10.06.04, em caso de falsa declaração sobre antecedentes penais, por empregado que postulou emprego em serviço de segurança.

53 A propósito do dolus bonus, JOSSERAND, Louis. Cours de droit civil positif français. Paris: Sirey, 1933. II, n. 94, p. 48/49, MIRANDA, Francisco Cavalcanti Pontes de. Tratado de direito privado. cit., 1954, tomo IV, $\S 449$, n. 1. p. 327. RODRIGUES, Silvio. Dos vícios do consentimento. São Paulo: Sarariva, 1982. n. 80, p. 
Por fim, se o empregador formula questão em torno de assunto que lhe é defeso investigar, como - para retomar os exemplos citados - convicção política, preferências sexuais ou crença religiosa do candidato ao emprego, há não apenas o direito de não responder à indagação como, ainda mais, o de prestar informação falsa. Tratase do chamado "droit au mensonge", mencionado pela doutrina suíça. ${ }^{54}$ A falsa resposta caracteriza legítima defesa do trabalhador contra ato de intromissão indevida em sua intimidade, o que afasta a ilicitude da conduta, na forma do art. 188, inciso I, do Código Civil.

Em princípio não se deve admitir a obtenção de informações do empregado sem o seu prévio conhecimento e consentimento, como, aliás, expressamente disposto no Personal Information Protection and Electronic Documents Act do Canadá, norma geral sobre proteção de informação, aplicável também às relações de trabalho. Ressalvem-se, todavia, casos excepcionais, como, por exemplo, os de relevante interesse da informação ou de seu caráter público. ${ }^{55}$

\section{Direito à intimidade e exames médicos}

Relativamente aos exames médicos, há, tal como em matéria de informação exigível do empregado, os que são obrigatórios, os que são permitidos e os que são proibidos. O art. 168, da CLT, caput, trata dos primeiros. Poderão ser feitos ainda outros exames, além dos obrigatórios, desde que - como expresso no art. 19º n. 1, do Código do Trabalho de Portugal, melhor redigido que o art. 168, $\S 2^{\circ}$, da CLT - "tenham por finalidade a proteção e segurança do trabalhador ou de terceiros, ou quando particulares exigências inerentes à actividade (os) justifiquem". Na jurisprudência brasileira chegou-se mesmo a admitir o uso do polígrafo, ante o interesse público na preservação da segurança de certas atividades, ${ }^{56}$ o que se afigura excessivo. O interesse público não justifica toda e

140, e SANTOS, J. M. de Carvalho. Código civil brasileiro interpretado. Rio de Janeiro: Metropole, 1936. vol. II, p. 341. Em jurisprudência, admitindo a legitimidade do dolus bonus, em matéria penal, STJ $-6^{\mathrm{a}}$ T., RHC n. 3831/RJ, Rel. Min. Luiz Vicente Cernicchiaro, julg. em 13.09.94 in DJ 28.11.1994, p. 32641, e, em material civil, TJ-RJ, 15a Câm. Civ., Proc. n. 1998.001.02703, Rel. Des. Luiz Fux, julg. em 25.11.98.

54 Para discussão do assunto, com boa indicação bibliográfica, cf. WYLER, Rémy. Droit du travail. cit., p. 229.

55 Dispõe, a propósito, o art. 7, (1), do Personal Information Protection and Electronic Documents Act do Canadá: "For the purpose of clause 4.3 of Schedule 1, and despite the note that accompanies that clause, an organization may collect personal information without the knowledge or consent of the individual only if (a) the collection is clearly in the interests of the individual and consent cannot be obtained in a timely way; (b) it is reasonable to expect that the collection with the knowledge or consent of the individual would compromise the availability or the accuracy of the information and the collection is reasonable for purposes related to investigating a breach of an agreement or a contravention of the laws of Canada or a province; (c) the collection is solely for journalistic, artistic or literary purposes; or (d) the information is publicly available and is specified by the regulations".

56 "Contrato de transporte aéreo de pessoas e coisas - segurança - Há que se considerar, que a empresa, 
qualquer quebra da intimidade, cuja salvaguarda é também de interesse público. Como decidiu a United States Court of Appeals for the Sixth Circuit, "a drug testing program may also be unconstitutional...even if the government establishes a sufficient special need, if the intrusion upon the individual's privacy interest were excessive, for instance, because of an overly intrusive testing procedure". ${ }^{7}$

Por fim, certos exames estão proibidos, alguns de modo expresso, outros de forma implícita. Proibição expressa existe relativamente a exame para apuração de gravidez ou de esterilidade, nos termos da Lei n. 9.029. É preciso, contudo, compreender na justa medida a proibição, voltada a proteger a gestante. Se a atividade a ser desenvolvida puder implicar risco para o feto, como no caso de atividade que envolva contado com radiações ionizantes ou substâncias tóxicas, não se vê como possa ser proibido o exame de gravidez. A solução, no caso, envolve admitir o exame, mas preservar o sigilo do resultado. Ao médico cabe, tão somente, enunciar a aptidão ou inaptidão da empregada, considerada a atividade que será por ela realizada. É a solução posta, sob a inspiração da já citada Diretiva Directiva 95/46/CE do Parlamento Europeu e do Conselho, de 24 de Outubro de 1995, pelo art. 19º, ns. 2 e 3, do Código do Trabalho de Portugal: "2. O empregador não pode, em circunstância alguma, exigir da candidata a emprego ou da trabalhadora a realização ou apresentação de testes ou exames de gravidez. 3. O médico responsável pelos testes e exames médicos só pode comunicar ao empregador se o trabalhador está ou não apto para desempenhar a actividade" ${ }^{58}$ É algo que se justifica plenamente, pois, como decidiu o Tribunal Constitucional de Portugal, ao examinar a constitucionalidade da redação original do Código do Trabalho, "O empregador não tem necessidade de conhecer directamente dados relativos à esfera íntima do candidato a emprego ou do trabalhador,

hodiernamente e em tempos de globalização, vem se amoldando cada vez mais à dinâmica social, tem um novo papel no contexto social eis que, como empregador, não é mais um simples empreendimento em busca de lucros para um pequeno grupo, afastando-se cada vez mais de sua antiga visão privatística, para assumir não só os riscos do negócio, mas também a responsabilidade pelos seus empregados, pelas garantias da personalidade e da dignidade humanas. A subsunção do teste do polígrafo não tem por finalidade a salvaguarda do patrimônio da empresa, mas a segurança da população em geral e clientes em particular."(TRT - $2^{\mathrm{a}}$ Reg., $10^{\mathrm{a}}$ T., RO n. 00735200203602002 , Rel. Juíza Vera Marta Publio Dias, Ac. n. 20040242581 in DOE de 01.06.04).

57 International Union; United Automobile, Aerospace and Agricultural Implement Workers of America v. Janine Winters, et al. (n. 03-1574).

58 A origem da previsão do Código do Trabalho de Portugal é o texto do art. $8^{\circ}$, da Directiva 95/46/CE. O seu art. $8^{\circ}$, n. 1, depois de estabelecer a obrigação de os Estados Membros da União Européia proibirem "o tratamento de dados pessoais que revelem a origem racial ou étnica, as opiniões políticas, as convicções religiosas ou filosóficas, a filiação sindical, bem como o tratamento de dados relativos à saúde e à vida sexual", no item 3, estabelece: "O n. 1 não se aplica quando o tratamento dos dados for necessário para efeitos de medicina preventiva, diagnóstico médico, prestação de cuidados ou tratamentos médicos ou gestão de serviços da saúde e quando o tratamento desses dados for efectuado por um profissional da saúde obrigado ao segredo profissional pelo direito nacional ou por regras estabelecidas pelos organismos nacionais competentes, ou por outra pessoa igualmente sujeita a uma obrigação de segredo equivalente". 
bastando-lhe obter a informação da eventual existência de inconvenientes à contratação ou à atribuição de determinadas actividades". ${ }^{59}$

Não se devem aceitar outros exames que, embora não estejam formalmente proibidos, envolvam práticas discriminatórias, como seria o caso daquele destinado a apurar, por exemplo, a origem étnica do empregado ou o risco de desenvolver, no futuro, certas doenças.

9. Bilateralidade do direito à intimidade

Cumpre não adotar, no exame do direito à intimidade, concepção unilateral, como a subjacente no Statuto dei diritti dei lavoratori, que se ocupa apenas da tutela do empregado. Embora essa tutela seja, sem sombra de dúvida, a mais importante em termos práticos, é preciso não perder de vista que a proteção legal da personalidade, especialmente no tocante à intimidade, estende-se igualmente ao empregador, conclusão a que se chega por vários fundamentos.

De um lado, há a regra do art. 52, do Código Civil, havendo quem afirme terem as pessoas jurídicas direitos de personalidade. ${ }^{60}$ De outro, está pacificada, nos termos da Súmula 227, do Supremo Tribunal Federal, a possibilidade de também a pessoa jurídica sofrer dano moral. Finalmente, o empregador pode ser também pessoa física ou natural, caso em que mais relevante ainda se torna a tutela da sua intimidade. Não raro o empregado, no exercício de suas funções, toma contato com informações pessoais do empregador, as quais também ficam sujeitas a reserva. Oportuna, pois, a previsão do art. $16^{\circ}$, n. 1, do Código do Trabalho de Portugal, com o seguinte teor: "O empregador e o trabalhador devem respeitar os direitos de personalidade da contraparte, cabendolhes, designadamente, guardar reserva quanto à intimidade da vida privada". A hipótese do empregado doméstico, que conhece a vida íntima do empregador e de sua família, é suficientemente expressiva e dispensa outras referências.

Ressalte-se, outrossim, que o fato de haverem sido as informações sobre a intimidade da pessoa obtidas com a concordância do titular do direito de personalidade não as torna suscetíveis de divulgação, ao contrário do que pareceu a Adriano de Cupis. ${ }^{61}$

\footnotetext{
59 Acórdão n. 306/2003, de 25.06.2003, Rel. Conselheiro Mário José de Araújo Torres, item n. 9.

60 PERLINGIERI, Pietro. Profili istituzionali del diritto civile. Camerino: Jovene, 1975. p. 2002, e, na doutrina nacional, DINIZ, Maria Helena. Código Civil anotado. São Paulo: Saraiva, 2002. p. 68.

61 DE CUPIS, Adriano. I diritti della personalità. Milano: Giuffrè, 1959. tomo I, n. 141, p. 355.
} 


\section{Dever de sigilo}

As informações obtidas antes da celebração do contrato ou durante a sua vigência, por qualquer meio ou forma, encontram-se protegidas por dever de sigilo. ${ }^{62}$ Mais ainda, ao titular da informação cabe tomar todas as cautelas para que ela não seja devassada. A preocupação com a proteção de dados é constante no direito comparado. Em França, por exemplo, a Lei n. 78-17, de 6 de janeiro de 1978, sobre informática, arquivos e liberdades, estabelece, em seu art. 34:

Le responsable du traitement est tenu de prendre toutes précautions utiles, au regard de la nature des données et des risques présentés par le traitement, pour préserver la sécurité des données et, notamment, empêcher qu'elles soient déformées, endommagées, ou que des tiers non autorisés y aient accès. ${ }^{63}$

A obrigação de sigilo não desaparece por haverem sido eventualmente transmitidas as informações, por determinação legal, a órgãos públicos. A regra do art. $5^{\circ}$, inciso XIV, da Constituição, não implica dever de divulgação, a quem quer que seja, de informações de caráter reservado. No direito norte-americano, a despeito de o Capítulo 5, do U.S.C., § 552(a), determinar, nos termos do Freedom of Information Act (FOIA), que os órgão governamentais permitam o acesso público a certas informações, o item (b) (7) (C) do mesmo texto ressalva não se aplicar a determinação "to matters that are... records or information compiled for law enforcement purposes, but only to the extent that the production of such law enforcement records or information...could reasonably be expected to constitute an unwarranted invasion of personal privacy". Interpretando esse dispositivo, a Suprema Corte norte-americana registrou: "As a general rule, if the information is subject to disclosure, it belongs to all. When disclosure touches upon certain areas defined in the exemptions, however, the statute recognizes limitations that compete with the general interest in disclosure, and that, in appropriate cases, can overcome it" ${ }^{64}$

Assim, as informações obtidas em decorrência do contrato de trabalho, tanto pelo empregado como pelo empregador ou mesmo por órgão público, não podem, em princípio, ser reveladas a terceiros, sem o consentimento do interessado. ${ }^{65}$ É inconcebível, por exemplo, que o empregador, valendo-se da informação que dispõe sobre a morada e os ganhos do empregado, transfira dados a empresas interessadas em divulgar certos produtos em determinada região da cidade, a pessoas com determinado poder aquisitivo.

\footnotetext{
62 BARACAT, Eduardo Milléo. A boa-fé no direito individual do trabalho. cit., p. 237.

63 Redação dada pela Lei n. 2004-801, de 6 de agosto de 2004.

64 National Archives and Records Administration v. Favish et al. (certiorari n. 02-954).

65 SIMÓN, Sandra Lia. A proteção constitucional da intimidade e da vida privada do empregado. cit., p. 164.
} 
É claro que se deve ressalvar a ocorrência de motivo relevante para a transmissão a terceiro da informação obtida no curso do contrato de trabalho. Em Portugal, a Lei n. 67/98, de 26 de Outubro, conhecida como "Lei da protecção de dados pessoais", no art. $17^{\circ}$, ao tratar do sigilo profissional, estatui: " 1 - Os responsáveis do tratamento de dados pessoais, bem como as pessoas que, no exercício das suas funções, tenham conhecimento dos dados pessoais tratados, ficam obrigados a sigilo profissional, mesmo após o termo das suas funções. 2 - Igual obrigação recai sobre os membros da CNPD (Comissão Nacional de Protecção de Dados), mesmo após o termo do mandato. 3 - O disposto nos números anteriores não exclui o dever do fornecimento das informações obrigatórias, nos termos legais, excepto quando constem de ficheiros organizados para fins estatísticos". Exemplos de situações em que o sigilo é posto de lado envolvem instrução de processo, identificação de doença de notificação compulsória ou esclarecimento, amparado por lei, de autoridade pública. ${ }^{66}$

Tampouco se mostra ilícito transferir a terceiro a informação quando em causa esteja a regular prestação de serviço ao empregador, detentor da informação. É aceitável, para mencionar uma hipótese expressiva e atual, transmitir a escritório de contabilidade, responsável pela confecção da folha de pagamento da empresa, dados relacionados com o salário dos empregados do tomador de serviço do mesmo escritório. Fica o prestador de serviço, porém, sujeito à mesma obrigação imposta ao empregador, de preservação do sigilo dos dados informados, não os podendo utilizar em seu próprio interesse. A situação foi considerada pela já citada Lei francesa n. 78-17, de 6 de janeiro de 1978, sobre informática, arquivos e liberdades, a qual, no art. 35, estabelece:

Les données à caractère personnel ne peuvent faire l'objet d'une opération de traitement de la part d'un sous-traitant, d'une personne agissant sous l'autorité du responsable du traitement ou de celle du sous-traitant, que sur instruction $\mathrm{du}$ responsable du traitement. Toute personne traitant des données à caractère personnel pour le compte du responsable du traitement est considérée comme un sous-traitant au sens de la présente loi. Le sous-traitant doit présenter des garanties suffisantes pour assurer la mise en oeuvre des mesures de sécurité et de confidentialité mentionnées à l'article 34 . Cette exigence ne décharge pas le responsable du traitement de son obligation de veiller au respect de ces mesures. ${ }^{67}$

No direito português exige-se, ainda mais, contrato escrito que vincule o subcontratado às obrigações impostas ao detentor da informação. ${ }^{68} \mathrm{~A}$ exigência constitui

\footnotetext{
${ }_{66}$ Cf. art. 7, (3), do Personal Information Protection and Eletronic Documents Act, do Canadá.

67 Redação dada pela Lei n. 2004-801, de 6 agosto de 2004.

68 Trata-se do $14^{\circ}$, n. 3, da Lei n. 67/98, assim redigido: “A realização de operações de tratamento em
} 
superfetação, voltada apenas a afastar dúvida e a explicitar a obrigação, que existe mesmo sem previsão em contrato, pois decorre de imposição legal. Fosse de outro modo, tornarse-ia dispositiva a exigência de proteção do sigilo dos dados, que poderia ser deixada de lado, mediante simples transferência das informações a algum prestador de serviço. Em outros termos, a transmissão legítima da informação a terceiro não exonera o empregador da responsabilidade de preservar o seu sigilo. Ainda que possa agir em face do prestador de serviço, em caso de quebra do sigilo, continuará a ser diretamente responsável, perante o empregado, pelos danos que este último vier a sofrer, por conta da divulgação indevidamente realizada.

11. Tutela da intimidade

A tutela do direito à intimidade manifesta-se de modo amplo e em diferentes planos.

Primeiro desdobramento dessa tutela é o dever de preservação do sigilo, examinado no item anterior. Como conseqüência, simples ameaça de quebra do sigilo já é bastante para que se busque a devida proteção, sob forma cautelar. A ofensa, depois de consumada, nem sempre comporta reparação adequada ou suficiente, pelo que a prevenção adquire enorme relevância, tanto que o próprio art. 12, do Código Civil, aludiu à possibilidade de pedir-se "que cesse a ameaça...a direito de personalidade". Previsão semelhante encontra-se no Código Civil suíço. Dispõem os arts. 28, n. 1, e 28c, n. 1, respectivamente: "Celui qui subit une atteinte illicite à sa personnalité peut agir en justice pour sa protection contre toute personne qui y participe"; e "Celui qui rend vraisemblable qu'il est l'objet d'une atteinte illicite, imminente ou actuelle, et que cette atteinte risque de lui causer un préjudice difficilement réparable, peut requérir des mesures provisionnelles". Tem plena incidência no direito brasileiro, portanto, o art. 273, do CPC, aplicável subsidiariamente no direito processual do trabalho, na forma do art. 769, da CLT. ${ }^{69}$ Anunciada pela empresa, por exemplo, a divulgação, em futuro próximo, de dados reservados dos empregados em sistema interno de informação, pode-se pedir provimento liminar destinado a obstar que se concretize o plano.

Sobrevindo violação ao direito à intimidade, cabe postular tanto que ela cesse como, ainda, reparação do dano, sem prejuízo, evidentemente, da rescisão motivada do contrato de trabalho, nos termos da aliena "b", do art. 483, da CLT, ou, conforme a hipótese, da aliena “e”, do mesmo preceito. A realização de revista íntima pelo empregador,

subcontratação deve ser regida por um contrato ou acto jurídico que vincule o subcontratante ao responsável pelo tratamento e que estipule, designadamente, que o subcontratante apenas actua mediante instruções do responsável pelo tratamento e que lhe incumbe igualmente o cumprimento das obrigações referidas no n. 1".

69 Cf. MALLET, Estêvão. Antecipação da tutela no processo do trabalho. São Paulo: LTr, 1999. p. 123. 
por exemplo, dá margem à emissão de ordem de abandono da prática, sob pena de aplicação de multa ou de outra medida adequada $\left(\mathrm{CPC}\right.$, art. $\left.461, \S 5^{\circ}\right)$, e, bem assim, à condenação no pagamento de indenização (parágrafo único, do art. 953, do Código Civil), na linha do que decidiu o Tribunal Superior do Trabalho: "1. O Eg. Tribunal Regional consignou que o Reclamante era submetido a revistas visuais cotidianas, nas quais estava obrigado a se despir na frente de terceiros. 2. O poder fiscalizatório do empregador de proceder às revistas encontra limitação na garantia de preservação da honra e intimidade da pessoa física do trabalhador, conforme preceitua o art. $5^{\circ}$, inciso $\mathrm{X}$, da Constituição da República. 3. A realização de revistas sem a observância dos limites impostos pela ordem jurídica acarreta ao empregador a obrigação de reparar, pecuniariamente, os danos morais causados".70

Já a extração de informação contrária ao direito do empregado à intimidade permite tanto que se postule a condenação do empregador a não se utilizar do conhecimento obtido como ainda a destruir o registro em que contida essa informação, tudo sem prejuízo, ademais, de indenização, prevista expressamente, por exemplo, no Data Protection Act britânico, em cuja seção 13 (1) lê-se: “An individual who suffers damage by reason of any contravention by a data controller of any of the requirements of this Act is entitled to compensation from the data controller for that damage". ${ }^{71}$

Não se afasta, tampouco, a possibilidade de ordem de retificação de informação que, embora deva ser preservada e não possa, por isso mesmo, sujeitar-se a destruição, se encontre em desacordo com a realidade. É algo que se prevê expressamente em vários ordenamentos jurídicos, como, por exemplo, no Code Civil do Québec, em cujo art. 40 estatui-se: "Toute personne peut faire corriger, dans un dossier qui la concerne, des renseignements inexacts, incomplets ou équivoques; elle peut aussi faire supprimer un renseignement périmé ou non justifié par l'objet du dossier, ou formuler par écrit des commentaires et les verser au dossier”. Em Portugal, a já citada Lei n. 67/98, estabelece, no seu art. $11^{\circ}$, o direito do titular de dados de "obter do responsável pelo tratamento, livremente e sem restrições, com periodicidade razoável e sem demoras ou custos excessivos:...d) A rectificação, o apagamento ou o bloqueio dos dados cujo tratamento não cumpra o disposto na presente lei, nomeadamente devido ao carácter incompleto ou inexacto desses dados". Trata-se de decorrência do que, para alguns autores, configuraria verdadeiro princípio, a saber, o princípio da atualização, segundo o qual os dados e as informações devem corresponder à realidade, quer dizer, "à situação do titular". ${ }^{2}$

70 TST - 8 ${ }^{a}$ T., RR n. 928/2004-006-06-00.1, Rel. Min. Maria Cristina Peduzzi in DJU de 07.03.2008.

71 Cf., a propósito, DEAKIN, Simon; MORRIS, Gillian S. Labor law. London: Butterworths, 2003. p. 352.

72 GUERRA, Amadeu. A privacidade no local de trabalho. cit., p. 69. 
Enfim, e como pondera José de Oliveira Ascensão, podem ser requeridas, em matéria de tutela dos direitos de personalidade, as providências adequadas, que não estão taxativamente previstas em lei, e ficam "a determinar perante as circunstâncias do caso concreto". ${ }^{73}$ Nessa linha, o art. 16, do Personal Information Protection and Electronic Documents Act do Canadá confere amplos poderes ao juiz para determinar a medida adequada em caso de violação ao dever de sigilo, preceituando: "The Court may, in addition to any other remedies it may give, (a) order an organization to correct its practices in order to comply with sections 5 to 10 ; (b) order an organization to publish a notice of any action taken or proposed to be taken to correct its practices, whether or not ordered to correct them under paragraph (a); and (c) award damages to the complainant, including damages for any humiliation that the complainant has suffered". Assim, lançada, na carteira de trabalho do empregado, informação desabonadora, além da indenização pelo dano, tanto se concebe a ordem de riscadura do registro, por aplicação analógica da regra do art. 15, caput, do CPC, como, eventualmente, se mais recomendável, determinação de expedição de novo documento.

Muitas vezes a indenização é, embora incompleta e imperfeita, a única compensação possível para os que já foram atingidos pelo ato ilícito. Tal o caso, para retomar exemplo anterior, do empregado que, não trabalhando mais na empresa, foi submetido à revista íntima enquanto em vigor o seu contrato de trabalho.

O valor da indenização não se acha fixado em lei, até porque não há como medir monetariamente a extensão do dano perpetrado. Os limites previstos na Lei de Imprensa já não mais são invocáveis, ante os termos da Súmula 281, do Superior Tribunal de Justiça. ${ }^{74}$ A aplicação analógica do art. 478, caput, da CLT, com fixação de indenização correspondente a um mês de salário por ano de serviço, proposta mais de uma vez em jurisprudência, ${ }^{75}$ não escapa a crítica. A gravidade da lesão nem sempre guarda nexo com o valor do salário do empregado ou com o tempo de vigência do contrato de trabalho. ${ }^{76}$ Realmente, concebe-se seja produzido dano gravíssimo a empregado recém admitido e remunerado com salário bastante baixo ou, inversamente, dano pouco expressivo a empregado com largo tempo de serviço e salário elevado.

73 ASCENSÃO, José de Oliveira. Direito civil: teoria geral. cit., n. 50, p. 96, e n. 50-A, p. 97.

74 Preceitua a citada Súmula: "A indenização por dano moral não está sujeita à tarifação prevista na Lei de Imprensa".

75 TRT - $2^{\mathrm{a}}$ Reg, $8^{\mathrm{a}}$ T., RO n. 02970026044, Rel. Juíza Wilma Nogueira de Araújo Vaz da Silva, Ac. n. 02980038517, julg. em 26.01.1998 in DOE SP, PJ, de 10.02.1998; TRT 2 2a Reg., 9a T., RO n. 20000561970, Rel. Juiz Luiz Edgar Ferraz de Oliveira, Ac. n. 20010669773, julg. em 17.10.2001 in DOE SP, PJ, de 26.10.2001.

76 "Indenização por dano moral - Fixação do valor - Desvinculação do tempo de serviço e do salário. O valor da indenização por dano moral deve ser arbitrado levando-se em conta a gravidade da ofensa apenas, sem e considerar o tempo de serviço ou a remuneração percebida". (TRT - $9^{\text {a }}$ Reg., $4^{\text {a }}$ T., Ac. n. 6.896/98, Rel. Juiz Dirceu Júnior in DJPR de 03.04.1.998, p. 428). 
Em síntese, deve-se deixar de lado a idéia de indenização rigidamente tarifada. No direito romano mesmo, se inicialmente era definido, de modo antecipado, o valor fixo da indenização devida em caso de atentado à dignidade da pessoa, sem levar em conta as peculiaridades de cada situação, evoluiu-se para sistema de determinação do montante por meio de estimativa do juiz, ${ }^{77}$ que permite melhor harmonizar os ideais de justiça e de igualdade. ${ }^{78}$

A regra do parágrafo único, do art. 953, do Código Civil, que pretende indicar parâmetros para estabelecimento da indenização, quando não se prova prejuízo material, pouco esclarece, ante a vaga alusão às "circunstâncias do caso". Dela não se extrai esteja o julgador investido de "prudente arbítrio" para fixar o valor da indenização, diversamente do que já se sugeriu. ${ }^{79} \mathrm{O}$ arbítrio, mesmo quando prudente, é incompatível com a idéia de direito. ${ }^{80} \mathrm{Na}$ verdade, conquanto não exista precisa delimitação do valor da indenização devida em caso de prejuízo sem natureza material, há critérios cuja observância não se pode deixar de lado.

Em primeiro lugar, é preciso levar em conta a relevância do direito violado e a extensão da ofensa perpetrada. Divulgação de informação de menor importância, a apenas uma terceira pessoa, reclama condenação economicamente menos severa para o agressor do que se tivesse sido revelado aspecto particularmente íntimo da vida do empregado a todos os seus colegas de trabalho e mesmo a estranhos.

Também o grau de repreensibilidade da conduta do agente causador do dano deve ser considerado, consoante reiteradamente enfatizado pela doutrina britânica ${ }^{81}$ e norte-americana ${ }^{82}$ e mesmo pela jurisprudência em matéria de punitive damages. Na paradigmática decisão tomada em BMW of North America, Inc. v. Gore, por exemplo, a Suprema Corte dos Estados Unidos da América registrou: "Perhaps the most important indicium of the reasonableness of a punitive damages award is the degree of reprehensibility of the defendant's conduct". ${ }^{83}$ Se houve mera culpa, admite-se, no direito brasileiro, com

77 ACCARIAS, Calixte. Précis de droit roman. Paris: Librairie Cotillon, 1891. tome second, n. 677 , p. 492 e segs., e MAY, Gaston. Éléments de droit roman. Paris: Librairie de la Société du Recueil Général des Lois et des Arrêts, 1901. n. 183, p. 356 e ss.

78 É a justificativa que oferece Jhering à evolução correspondente à actio injuriarum aestimatoria (JHERING, Rudolf von. L'esprit du droit romain. Paris: Marescq, 1886. tome deuxième, § 33, p. 92).

79 GONÇALVES, Carlos Roberto. Comentários ao código civil. São Paulo: Saraiva, 2003. n. 142, p. 556. Em jurisprudência: TRT - 12 ${ }^{\mathrm{a}}$ Reg., $1^{\mathrm{a}}$ T., Ac. n. 2154/2002, Rel. Juiz Godoy Ilha in DJSC de 07.03.2002, p. 170 e TA-PR, 5a Câm. Cív., Ap. Cív. n. 142.289-3, Ac. 9790, Rel. Juiz Marques Cury in DJ de 22.10.1999.

80 LOPEZ ÕNATE, Flavio. La certeza del diritto. Roma: Casa Editrice Gismondi, 1942. p. 148.

81 Cf. GELDART, W. M. Elements of english law. New York: Henry Holt and Company, s. d. p., p. 210, e PATON, George Whitecross. A text-book of jurisprudence. Oxford: Claredon Press, 1972. p. 491.

82 KIONKA, Edward J. Torts. cit., p. 372. Cf. também, com indicação das origens e dos antecedentes históricos dos punitive damages, BELL, Griffin B.; PEARCE, Perry E. Punitive damages and the tort system. University of Richmond Law Review, v. 22, p. 1 e ss.

83 517U.S. 559. Ainda, no mesmo sentido, veja-se o julgamento mais antigo proferido também pela Suprema 
apoio no parágrafo único, do art. 944, do Código Civil, indenização menos elevada do que a atribuída em caso de dolo. ${ }^{84}$ Do mesmo modo, se o agente obrou de modo fraudulento sua conduta demanda sanção mais firme.

Por fim, não se deve perder de vista o caráter dissuasório - e não apenas reparatório - da indenização. ${ }^{85}$ Pode-se dizer que, embora não perca a indenização a sua função reparatória, se reveste também de função punitiva, ${ }^{86}$ como bem registrado na seguinte decisão: "Indenização por dano moral. Critério de fixação. A indenização por dano moral deve guardar correspondência com o dano e deve representar, ainda, uma sanção ao agressor, de modo a coibir a repetição dos atos lesivos"87. Logo, não se exclui que, deferida certa indenização por ofensa à intimidade do empregado, havendo repetição da ofensa ao mesmo direito, em idênticas condições, eleve-se o valor da condenação, para que não se repita novamente a conduta. Também por isso lesões com características juridicamente iguais podem dar margem a indenizações com valores diversos, tendo em conta a distinta capacidade econômica dos ofensores.

São Paulo, março de 2009.

Corte dos Estados Unidos da América em Scott v. Donald (165 U.S. 58). Sempre reiterando a orientação, cf., mais recentemente, State Farm Mutual Automobile Insurance Co. v. Campbell et al. (U.S. certiorari 011289) e, ainda, United States Court of Appeals for the Third Circuit, n. 03-2837, decisão de 14.02.05. Para a aplicação dessas diretrizes no campo das relações do trabalho, em caso de assédio moral de empregado, cf. decisão proferida pela United States Court of Appeals for the Eighth Circuit, n. 03-2976, em 06.08.04. Já para a aplicação das mesmas diretrizes em matéria de fraude relacionada com apostas por telefone, cf. decisão proferida pela United States Court of Appeals for the Eleventh Circuit, n. 03-15189, em 27.12.04.

${ }_{84}$ TRT $-3^{\mathrm{a}}$ Reg., $3^{\mathrm{a}}$ T., RO n. 00106-2002-092-03-00 (14.515/2002), Rel. Juiz Sebastião Geraldo de Oliveira, julg. em 18.12.2002 in DJMG de 25.01.2003, p. 10; TRT - $3^{\mathrm{a}}$ Reg., $2^{\mathrm{a}}$ T., RO n. 15.272/2000, Rel. Juíza Maristela Íris da Silva Malheiros, julg. em 24.04.2001 in DJMG de 23.05.2001, p. 20. Na jurisprudência de direito comum: STJ - $3^{\mathrm{a}}$ T., REsp. n. 256455, Rel. Min. Sálvio de Figueiredo Teixeira in DJU de 11.09.00. Na mesma linha, o Tribunal Federal suíço, em caso de acidente do trabalho, assinalou, ao fixar a indenização por dano moral: "Fixation de l'indemnité pour tort moral, compte tenu notamment des fautes du responsable et de la victime" (Recueil officiel des arrêts du Tribunal Fédéral suisse, Lausanne, 102 II 18, decisão de 19.01.76).

85 LINDON, Raymond. La création prétorienne en matière de droits de la personnalité et son incidence sur la notion de famille. Paris: Dalloz, 1974. n. 162, p. 89. Como escreve Richard A. Posner, "if compensation is the only purpose of the negligence system, it is indeed a poor system, being both costly and incomplete. Its economic function, however, is not compensation but the deterrence of inefficient accidents". (POSNER, Richard. Economic analysis of law. New York: Aspen Publisher, 1998. p. 220).

86 CHIRONI, Giampietro. La colpa nel diritto civile odierno. Torino: Fratelli Bocca, 1906. v. 2, n. 414bis, p. 329; MORRIS, Clarence. Punitive damages in tort cases. Harvard Law Review, v. 44, p. 1.174.

87 TRT $-3^{\text {a }}$ Reg., $2^{\text {a }}$ T., RO n. 808/2000, Rel. Juíza Taísa Maria Macena de Lima, julg. em 13.06.2000 in DJMG de 28.06.2000, p. 16. Ainda no mesmo sentido: "Na fixação da indenização do dano moral, deve o juiz se nortear por dois vetores: a reparação do dano causado e a prevenção da reincidência patronal. Vale dizer que, além de estimar o valor indenizatório, tendo em conta a situação econômica do ofensor, esse deve servir como inibidor de futuras ações lesivas à honra e boa fama dos empregados". (TST - $4^{\mathrm{a}}$ T., RR n. 641.571, Rel. Min. Antônio José de Barros Levenhagen, julg. em 05.02.2003 in DJU de 21.02.2003). 
Referências

ARAÚJO, Francisco Rossal de. A boa-fé no contrato de emprego. São Paulo: Ltr, 1996.

ASCENSÃO, Jose de Oliveira. Direito civil: teoria geral. Coimbra: Coimbra Editora, 2000.

ASSANTI, Cecília; PERA, Giuseppe. Commento allo dei diritti dei lavoratori. Padova: CEDAM, 1972.

BARACAT, Eduardo Milléo. A boa-fé no direito individual do trabalho. São Paulo: LTr, 2003.

BARKER, John. Constitutional privacy rights in the private workplace, under the federal end California constitutions. Hastings Constitutional Law Quarterly, v. 19, p. 1.107.

BLACK, Henry Campbell. Back’s Law Dictionary. St. Paul: West Publishing, 1968.

BLAPAIN, ROGER. Employee privacy issues: belgian report. Comparative Labor Law Journal, v. 17.

CLARK, R. H. Constitutional sources of the penumbral right to privacy. Villanova Law Review, v. 19.

CORRADO, Renato. Trattato di diritto del lavoro. Torino: UTET, 1969. v. 3.

DE CUPIS, Adriano. I diritti della personalità. Milano: Giuffrè, 1959. t. I.

DEAKIN, Simon; MORRIS, Gillian S. Labor law. London: Butterworths, 2003.

DINIZ, MARIA Helena. Código civil anotado. São Paulo: Saraiva, 2002.

FAVOREU, Louis et al. Droit des libertés fondamentales. Paris: Dalloz, 2000.

FERRARA, Francesco. Trattato di diritto civile italiano. Roma: Athenaum, 1921.

GARCÍA-NENET, José Ignácio. El estatuto de los trabajadores: comentarios a la Ley 8/1980. Madrid: Editoriales de Derecho Reunidas, 1981.

GAUDU, François; VATINET, Raymond. Les contrats du travail. Paria: LGDG, 2001.

GUERRA, Amadeu. A privacidade no local de trabalho. Coimbra: Almedina, 2004.

JAVILLIER, Jean-Claude. Droit du travail. Paris: Dalloz, 1999.

JOSSERAND, Louis. Cours de droit civil positif français. Paris: Sirey, 1933.

KIONKA, Edward J. Torts. St. Paul: West Publishing, 1977.

LE GOFF, Jacques. Droit du travail et société: les relations individuelles de travail. Rennes: Presses Universitaires de Rennes, 2001.

MAGANO, Octavio Bueno. Direito individual do trabalho. São Paulo: Ltr, 1992.

MAGANO, Octavio Bueno. Do poder diretivo na empresa. São Paulo: Saraiva, 1982.

MAGANO, Octavio Bueno. Manual de direito do trabalho. São Paulo: Ltr, 1990-92. v. 4. 
MALLET, Estêvão. Antecipação da tutela no processo do trabalho. São Paulo: LTr, 1999.

MEIRELLES, Edilton. O novo código civil e o direito do trabalho. São Paulo: Ltr, 2002.

MIRANDA, Francisco Cavalcanti Pontes de. Tratado de direito privado. Rio de Janeiro: Borsoi, 1955. t. 7.

PALOMEQUE LÓPEZ, Manuel Carlos; ALVAREZ DE LA ROSA, Manuel. Derecho del trabajo. Madrid: Editorial Centro de Estudios, 2001.

PERLINGIERI, Pietro. Profili istituzionali del diritto civile. Camerino: Jovene, 1975.

PLÁ RODRIGUEZ: Américo. Nuevos aportes sobre la protección a la intimidad del trabajador. In: Direito do trabalho: estudios em homenagem ao Professor Luiz de Pinho Pedreira da Silva. São Paulo: Ltr, 1998.

QUEIROZ, Cristina M. M. Direitos fundamentais: teoria geral. Coimbra: Coimbra Editora, 2002.

SANTOS, J. M. de Carvalho. Código civil brasileiro interpretado. Rio de Janeiro: Metropole, 1936. v. 2 .

SIMÓN, Sandra Lia. A proteção constitucional da intimidade e da vida privada do empregado. São Paulo: LTr, 2003.

SUSSEKIND, Arnaldo; CARVALHO, Luiz Inácio. Revista do empregado: limites. In: Direito do trabalho e previdência social: pareceres. São Paulo: Ltr, 1995.

VIVOT, Julio J. Martinez. Elementos del derecho del trabajo y de la seguridad social. Buenos Aires: Astrea, 1996.

WYLER, Rémy. Droit du travail. Berne: Staempli, 2002. 